\title{
Integrated self-validating thermocouples with a reference temperature up to $1329^{\circ} \mathrm{C}$
}

\author{
Declan Tucker ${ }^{1} \oplus$, Aurik Andreu ${ }^{2}$, Claire Elliott ${ }^{1}$, Trevor Ford ${ }^{3}$, \\ Marius $\mathrm{Neagu}^{4}$, Graham Machin ${ }^{1}\left[\right.$ and Jonathan Pearce ${ }^{1}\left[{ }^{[}\right.$ \\ 1 National Physical Laboratory (NPL), Hampton Road, Teddington, TW11 0LW, United Kingdom \\ 2 Advanced Forming Research Centre (AFRC), 85 Inchinnan Drive, Inchinnan, Renfrew, PA4 9LJ, \\ United Kingdom \\ ${ }^{3}$ CCPI Europe Limited, Temperature Technology Centre, Waleswood Way, Sheffield, S26 5NU, \\ United Kingdom \\ ${ }^{4}$ Biroul Român De Metrologie Legală Institutului National de Metrologie (BRML-INM), \\ Sos. Vitan Bârzesti, 11, Bucuresti-Sector 4, Bucuresti, Romania \\ E-mail: declan.tucker@npl.co.uk
}

Received 30 April 2018, revised 21 June 2018

Accepted for publication 7 August 2018

Published 31 August 2018

\begin{abstract}
Thermoelectric instability, or calibration drift, is a major problem for users of thermocouples at high temperature. NPL, in collaboration with CCPI Europe, AFRC and ICPE-CA/BRMLINM has designed, made and industrially tested Type $S$ thermocouples with integrated temperature fixed-point cells. These in situ, self-validating thermocouples (denoted 'inseva') have the same external dimensions as conventional industrial thermocouples (the recrystallised alumina sheath has an outer diameter 7 of $\mathrm{mm}$ ). The device can be used to detect the melting and/or freezing temperature of the integrated temperature fixed-point ingot, which enables a self-validation to be performed whilst in situ. During the testing, three different reference ingots were used in the cells, namely: copper $\left(1084{ }^{\circ} \mathrm{C}\right)$, cobalt-carbon $\left(1324^{\circ} \mathrm{C}\right)$ and nickel-carbon $\left(1329^{\circ} \mathrm{C}\right)$. The metrological performance for two iterations of the design are presented, with an emphasis on the ability of the inseva thermocouples to indicate their own thermoelectric stability. A measurement uncertainty budget is also given for the case of a Ni-C inseva thermocouple. This paper demonstrates that inseva thermocouples can be successfully validated during industrial processes through the observation of the melting plateau, as well as their robustness over time in industrial conditions. A key finding is that the $\mathrm{Ni}-\mathrm{C}$ eutectic alloy is much more robust than the $\mathrm{Co}-\mathrm{C}$ eutectic alloy for the used type of graphite crucible, making the $\mathrm{Ni}-\mathrm{C}$ inseva thermocouple more suitable for industrial applications, and a good alternative.
\end{abstract}

Keywords: self-validating, thermocouple, integrated, calibration, htfp, inseva

(Some figures may appear in colour only in the online journal)

\section{Introduction}

In general, thermocouples used at high temperatures (typically over $1000{ }^{\circ} \mathrm{C}$ ) will drift from their initial calibration state, resulting in an incorrect temperature reading which becomes worse with time [1]. In industrial applications, where the long term monitoring of high temperature processes or reliable repetition of thermal processes is vital, this can become a serious issue. Large temperature errors in process result in unnecessarily high energy costs, loss of time due to process disruption and excessive product rejection rates [2]. Industries particularly affected are in the aerospace, metal manufacturing and energy sectors, where heat treatment and the forging of components is done in challenging and harsh environments, and thermometry can suffer from large uncertainties.

The best measurement practice available to end users now involves the use of thermocouples calibrated in a laboratory over the temperature range of interest. This only 
provides a snapshot of information on performance before and, where possible, after use, making the in-process calibration drift difficult to determine. The calibration is typically performed using temperature fixed-point cells which, above room-temperature, make use of the well-known (or defined) temperatures of the melting (or freezing) of various metals to calibrate the thermovoltage reading from the thermocouple. Above $1100{ }^{\circ} \mathrm{C}$, metal-carbon eutectic ingots are used as the reference materials (known as high temperature fixed points, or HTFPs) [3]. Research has so far demonstrated practical temperature fixed-point cells for thermocouple calibrations up to about $2300{ }^{\circ} \mathrm{C}$ [4].

Self-validating thermocouples are of interest as they are expected to enable this laboratory-based technology to be moved into the industrial setting. Typically, a miniature temperature fixed point containing the phase-change ingot is integrated with the measurement junction of a thermocouple. The concept has been implemented in several different designs and trials [5-9] since Tischler and Koremblit's pioneering work with pure metals in 1982 [10].

The integrated temperature fixed point allows in situ calibration, which enable real-time calibration corrections to be made, yielding both increased confidence in the measurement and extended thermocouple lifetime, since in principle the interval between removals can be extended $[11,12]$.

To enable direct one-for-one replacement and straightforward adoption, a key requirement from industrial users for self-validating thermocouples is that they should be as indistinguishable from the conventional thermocouple as possible. There is the need, therefore, to retain (where possible) the same dimensions, connectivity and performance as existing thermocouples.

As part of the European Metrology Programme for Innovation and Research (EMPIR) project 'EMPRESS' (project label 14IND04), the design of the NPL slim-line inseva thermocouple has been developed and tested further than previously reported $[1,2]$. The temperature fixed-point cell (containing a $\mathrm{Cu}, \mathrm{Co}-\mathrm{C}$ or $\mathrm{Ni}-\mathrm{C}$ ingot) is integrated inside a standard, $7 \mathrm{~mm}$ outer diameter, recrystallised alumina protective sheath. The new design has resulted in significantly improved long-term repeatability and robustness over previous results. For example, one inseva thermocouple was in service for almost $9500 \mathrm{~h}$, and stayed within $2.5^{\circ} \mathrm{C}$ of the initial reading. Further, to demonstrate that the improved inseva thermocouple can operate in harsh industrial environments, in real manufacturing processes and is robust enough to continue measuring accurately for hundreds of hours, results of the first industrial trials are also presented.

Industrial trials were carried out at AFRC (Advanced Forming Research Centre, University of Strathclyde, United Kingdom) and ICPE-CA (Romanian National Institute for Research and Development in Electrical Engineering, Romania), with access facilitated by BRML-INM (Romanian National Institute of Metrology).

This paper is laid out such that firstly the self-validating thermocouple and associated miniature temperature fixedpoint cells are described. The results of tests at NPL of the
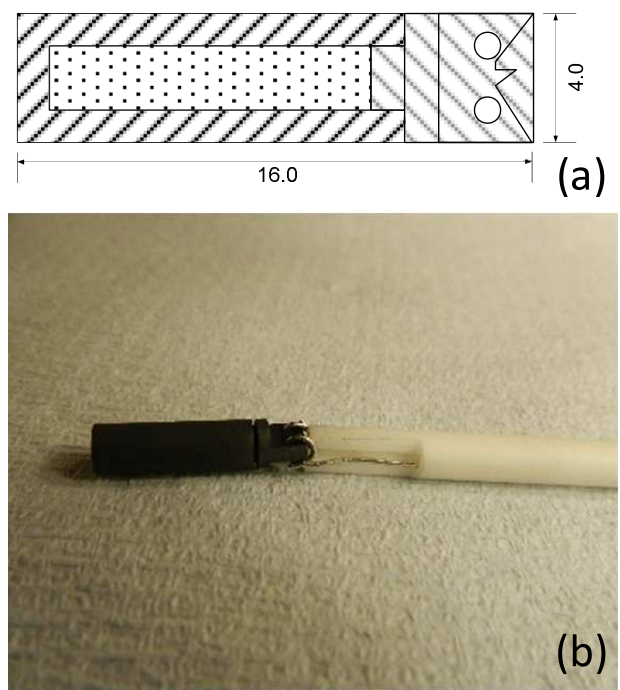

Figure 1. (a) Diagram of the inseva fixed-point cell, units in $\mathrm{mm}$. 1. (b) Photograph showing the arrangement of the fixed-point cell (black) and thermocouple wires.

original and improved design, and the industrial trials, are then presented. Finally, some discussion is included concerning the different temperature fixed points, the significantly better performance of the $\mathrm{Ni}-\mathrm{C}$ inseva thermocouple over the $\mathrm{Co}-\mathrm{C}$ alternative, and the measurement uncertainty associated with using the inseva thermocouple.

\section{Inseva thermocouple construction and design}

The NPL inseva thermocouple design consists of a graphite cell containing a metal ingot (figure 1(a)), where the lid of the cell is in thermal contact with the tip of a Type $S$ thermocouple. The cell is contained inside a sealed, argon-filled, alumina sheath with the thermocouple wires (figure 1(b)).

The inseva fixed-point cells were constructed from high purity Poco DFP-3-2 graphite, with manufacturer-stated purity of $99.9995 \%$. The manufacturer's stated purity of the $\mathrm{Cu}, \mathrm{Co}$ and $\mathrm{Ni}$ materials were $99.999 \%, 99.995 \%$ and 99.995\% respectively. Following techniques developed previously [13], the cells were then heated in an argon atmosphere inside a RD Webb 'Red Devil G' furnace to $1350{ }^{\circ} \mathrm{C}$ to drive off any other impurities prior to filling. The total length of the cell (including lid) is $16 \mathrm{~mm}$ and the outer diameter is $4 \mathrm{~mm}$. The ingot mass varied depending on the metal used, to allow for different thermal expansion, but was typically $0.3 \mathrm{~g}$. The metals were purchased in the form of $2 \mathrm{~mm}$ diameter wire which was cut and filed using a diamond file to the required length, cleaned with acetone as recommended in previous work [14] and placed inside the cell in an argon atmosphere before the lid was attached. Unlike larger fixed-point cells constructed at NPL, no additional graphite was added. Instead the natural uptake of carbon from the cell walls was used to enable the ingot to reach the eutectic alloy composition. Subsequently, because of issues with the cells that arose, a platinum-based inert barrier material was used to surround the cell in order to reduce the effect of oxidation and to reduce 
the amount of chemical interaction between the graphite cell and the thermoelements.

Type $\mathrm{S}$ thermocouples were used throughout this work with $0.5 \mathrm{~mm}$ diameter thermoelements. The outer protective sheath and the twin bore insulator material used for the thermocouples was high purity $(99.7 \%)$ recrystallised alumina. The sheath measured $7 \mathrm{~mm}$ in outer diameter, $5 \mathrm{~mm}$ in inner diameter and $700 \mathrm{~mm}$ in length. The inner diameter of the twin-bore insulator is $1.2 \mathrm{~mm}$. The hot junction ends of the thermoelements emerging from the twin bore insulator were attached to the inseva fixed-point cell and the whole assembly was inserted into the protective sheath which had been purged with high purity (99.9997\%) argon gas. The complete unit was sealed at the open end using epoxy to retain the internal argon atmosphere.

In total, six $\mathrm{Cu}$ inseva thermocouples (denoted $\mathrm{Cu} \boldsymbol{X}$ where $\boldsymbol{X}$ is the version letter), four $\mathrm{Co}-\mathrm{C}$ inseva thermocouples $(\mathrm{Co}-\mathrm{C} \boldsymbol{X})$, and two Ni-C inseva thermocouples (Ni-C $\boldsymbol{X}$ ) were constructed. AFRC and ICPE-CA each trialled one $\mathrm{Cu}$ inseva thermocouple in industrial conditions.

\section{Measurements}

\subsection{Tests at NPL (Cu)}

Tests at NPL were carried out in order to establish that the heating and cooling rates used during the industrial trials would not damage the inseva thermocouples.

Initial tests indicated that the orientation had no significant influence on the thermocouple performance, with comparable results being obtained whether the device was horizontal or vertical. As a result, so that parallel measurements could be carried out, the tests at NPL were carried out with the thermocouple held in either a short $(0.3 \mathrm{~m})$ single-zone, vertical furnace (Elite Thermal Systems TSV 18/15/100) or in a longer (1 m) single-zone horizontal Carbolite STF 15/610 furnace with the cell positioned in the hottest part of the furnace in both cases. These tests were carried out on four different $\mathrm{Cu}$ inseva thermocouples over a period of approximately 14 months.

The 24 hour $(\mathrm{h})$ furnace program cycle for the $\mathrm{Cu}$ inseva thermocouples used at the start of the pre-industrial trial testing was as follows:

1. Warm to $1105^{\circ} \mathrm{C}$ at a rate of $3.3^{\circ} \mathrm{C} \mathrm{min}-1$

2. Dwell at $1105^{\circ} \mathrm{C}$ for $3 \mathrm{~h}$

3. Cool to $1000{ }^{\circ} \mathrm{C}$ at a rate of $3.3^{\circ} \mathrm{C} \mathrm{min}{ }^{-1}$

4. Dwell at $1000^{\circ} \mathrm{C}$ for the remainder of the $24 \mathrm{~h}$ cycle.

This cycle was chosen as it closely resembled the program that the thermocouples would be experiencing at AFRC and was used to test the thermocouple to be used at ICPE-CA as well.

At NPL, the thermovoltage (EMF) was measured with a nano-voltmeter with $7 \frac{1}{2}$ digits and NPL software was used to perform the logging and to fit a 3rd order polynomial [15] to the EMF measurements around the melting inflection point using the least-squares method (figure 2). This inflection point occurs when the furnace temperature passes through the

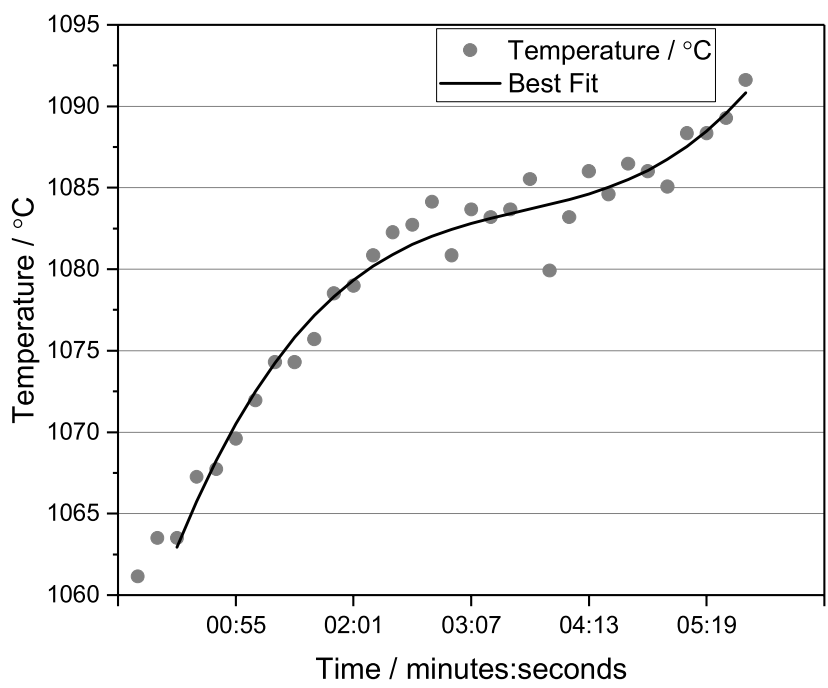

Figure 2. The temperature measured by a $\mathrm{Cu}$ inseva thermocouple as the furnace is heated through $1084{ }^{\circ} \mathrm{C}$ plotted together with the corresponding best fit polynomial.

melting temperature of the metal ingot. The melting point is used as it has been found to be more reliable than the freezing point [16].

\subsection{Industrial trials at ICPE-CA (Cu)}

At ICPE-CA, the trials were carried out with the thermocouple inserted horizontally in a VEB Guntersberge R09 furnace used for processing ceramic materials. The furnace uses silicon carbide heaters and is controlled by a Type $\mathrm{S}$ thermocouple. At ICPE-CA, two different programs were used where the temperature exceeded the melting temperature of $\mathrm{Cu}$, which are as follows:

- Sintering treatment 1: The furnace is heated to a temperature of $1100{ }^{\circ} \mathrm{C}$ at a rate of $3.8^{\circ} \mathrm{C} \mathrm{min}-1$, held for $2 \mathrm{~h}$, and then cooled to room temperature

- Sintering treatment 2: The furnace is heated to a temperature of $1100{ }^{\circ} \mathrm{C}$ at a rate of $4{ }^{\circ} \mathrm{C} \mathrm{min}{ }^{-1}$, held for $2 \mathrm{~h}$, and then cooled to room temperature

These tests were carried out on a single $\mathrm{Cu}$ inseva thermocouple over a period of approximately 11 months. The data were collected using a nano-voltmeter with 5 digits connected to a desktop PC.

\subsection{Industrial trials at $A F R C(\mathrm{Cu})$}

At AFRC, the trials were carried out with the thermocouple inserted horizontally into the wall of a bespoke CMI Gas Furnace, with a maximum temperature of $1200{ }^{\circ} \mathrm{C}$, the heat being produced by two BIC $80(90 \mathrm{~kW})$ burners. The thermocouple was positioned so that the thermocouple measurement junction (and inseva fixed-point cell) was in the $0.7 \mathrm{~m}^{3}$ uniform volume at the centre of the furnace. The furnace program used was the same as the one used initially at NPL and described in section 3.1. These trials were carried out intermittently on a single $\mathrm{Cu}$ inseva thermocouple over a period of approximately 


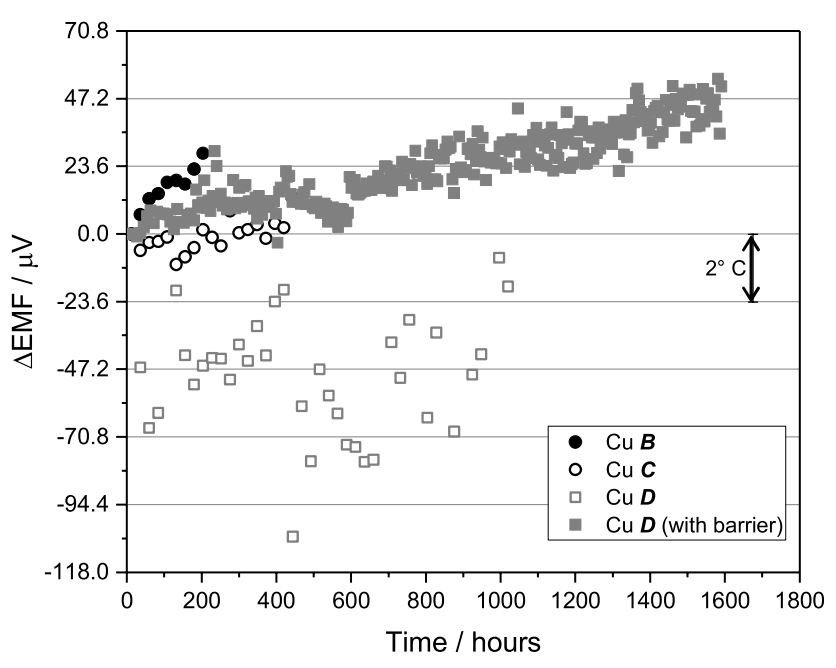

Figure 3. EMF of the melting inflection point as a function of time during the testing of four $\mathrm{Cu}$ inseva thermocouples at NPL.

8 months. The data were logged using a nano-voltmeter with $6 \frac{1}{2} 2$ digits connected to a desktop PC running NPL software.

\subsection{Tests at NPL (Co-C and $\mathrm{Ni}-\mathrm{C})$}

For the $\mathrm{Co}-\mathrm{C}$ and $\mathrm{Ni}-\mathrm{C}$ inseva thermocouples tested at NPL, the thermocouples were heated to a temperature of $1305^{\circ} \mathrm{C}$, then cycled between this point and $1330{ }^{\circ} \mathrm{C}$ for the $\mathrm{Co}-\mathrm{C}$ thermocouple, or $1335{ }^{\circ} \mathrm{C}$ for the Ni-C thermocouples, using a ramp rate of $5^{\circ} \mathrm{C} \min ^{-1}$.

\section{Results and discussion}

\subsection{Tests at NPL (Cu)}

The thermocouples $(\mathrm{Cu} \boldsymbol{B}$ and $\mathrm{Cu} \boldsymbol{C})$ had already undergone several hours of use as part of the initial test plan (described elsewhere [1]) before being used for this test. In figure 3, it can be seen that three of the four $\mathrm{Cu}$ thermocouples tested at NPL had a stability of better than $\pm 2.5^{\circ} \mathrm{C}$. $\mathrm{Cu} \boldsymbol{B}$ was stable to $\pm 1.5^{\circ} \mathrm{C}$ over $200 \mathrm{~h}$, and the measured EMF for the melting inflection point drifted by a maximum of $28 \mu \mathrm{V}$ before exhibiting mechanical failure. $\mathrm{Cu} C$ was stable to $\pm 0.6{ }^{\circ} \mathrm{C}$ over $450 \mathrm{~h}$, and the measured EMF for the melting inflection point drifted by a maximum of $13 \mu \mathrm{V}$ before failing, also mechanically. $\mathrm{Cu} \boldsymbol{D}$ showed greater robustness, lasting just over $1000 \mathrm{~h}$ until failing, this time due to separation of the cell lid from the cell body. The EMF of $\mathrm{Cu} \boldsymbol{D}$ for the melting inflection point, on the other hand, drifted by up to $105 \mu \mathrm{V}$, and so was only stable to $\pm 5.0^{\circ} \mathrm{C}$ over $1000 \mathrm{~h}$.

When taken apart and inspected, it was found that, for $\mathrm{Cu}$ $\boldsymbol{B}$ and $\mathrm{Cu} \boldsymbol{C}$ inseva thermocouples, the graphite cells showed signs of oxidation and mechanical damage (such as surface pitting, the lid becoming detached and the cell cracking). For $\mathrm{Cu} \boldsymbol{C}$, the crack in the graphite wall had resulted in the leakage of $\mathrm{Cu}$. In these and also the $\mathrm{Co}-\mathrm{C}$ inseva thermocouples described in section 3.4, the thermoelements had also broken near the cell in most cases. Chemical analysis (figure
4 and table 1) showed that, in general, a significant amount of carbon had become embedded in the metallic structure of the wire. This embrittled the wires and made them liable to break. The concentration of carbon was highest in the region of the wires where the breakage occurred.

In order to prevent or reduce the issues of both graphite oxidation and wire embrittlement, coating the inseva fixed-point cell with an inert barrier material was tested. The cell from $\mathrm{Cu} \boldsymbol{D}$ had a new lid fitted and was coated with this material, and a new inseva thermocouple with new thermoelements was made and tested. For the first 20 cycles, the thermocouple was heated and cooled between $1060{ }^{\circ} \mathrm{C}$ and $1090{ }^{\circ} \mathrm{C}$, dwelling for $4 \mathrm{~h}$ at each set point. After the initial 20 cycles, the dwell time was reduced to $2 \mathrm{~h}$ at each point. This device showed improved robustness: lasting $1600 \mathrm{~h}$ at high temperature, with no sign of damage (it was still functioning correctly at the end of the test). The EMF of the melting point increased by $54 \mu \mathrm{V}$ over the test period, which corresponds to a stability of $\pm 2.4^{\circ} \mathrm{C}$. This linear drift is probably due to thermoelectric drift of the thermocouple, not drift of the cell melting temperature (see an example of the stability of recalibration, posttest, in section 4.3). These excellent results suggest that the barrier material has in fact stopped or slowed the oxidation of the inseva fixed-point cell and thermoelements.

\subsection{Industrial trials at ICPE-CA (Cu)}

After calibration at NPL, a newly manufactured $\mathrm{Cu}$ inseva thermocouple was sent to ICPE-CA. This was installed in the furnace in December 2016 and removed in October 2017. The measurements made in-process demonstrated that the melting plateau of the $\mathrm{Cu}$ inseva fixed-point cell could still be detected whilst an industrial sintering process was being carried out (an example is shown in figure 5). During this time, 33 separate melting inflection points were recorded, in addition to a calibration performed in a full-sized $\mathrm{Cu}$ fixedpoint cell at NPL at the start and end of trialling. The EMF of the inflection points recorded in process were different to the calibrated EMF by up to $30 \mu \mathrm{V}$ (figure 6), and this variation corresponds to a stability of $\pm 1.5^{\circ} \mathrm{C}$. The origin of the step change seen in the data is thought to be caused by the position of the thermocouple changing when the furnace heating elements were changed after approximately $6000 \mathrm{~h}$. If this effect of moving the thermocouple during the trial is disregarded, the stability of the inseva thermocouple can be considered to be $\pm 1{ }^{\circ} \mathrm{C}$. The thermocouple was also in process during silvering and degassing processes, but these processes were either not hot enough for the inseva ingot to melt, or not recorded (table 2).

The measurements during the course of this trial provide assurance that the thermocouple was robust enough to remain operational for 11 months, in industry. Once trialling was complete, the thermocouple was recalibrated at NPL, with a difference between the starting and ending EMF of only $5 \mu \mathrm{V}$. Type $\mathrm{S}$ thermocouple calibrations at the $\mathrm{Cu}$ point, at NPL, have an uncertainty of $\pm 3.08 \mu \mathrm{V}$, suggesting negligible drift of the thermocouple. 


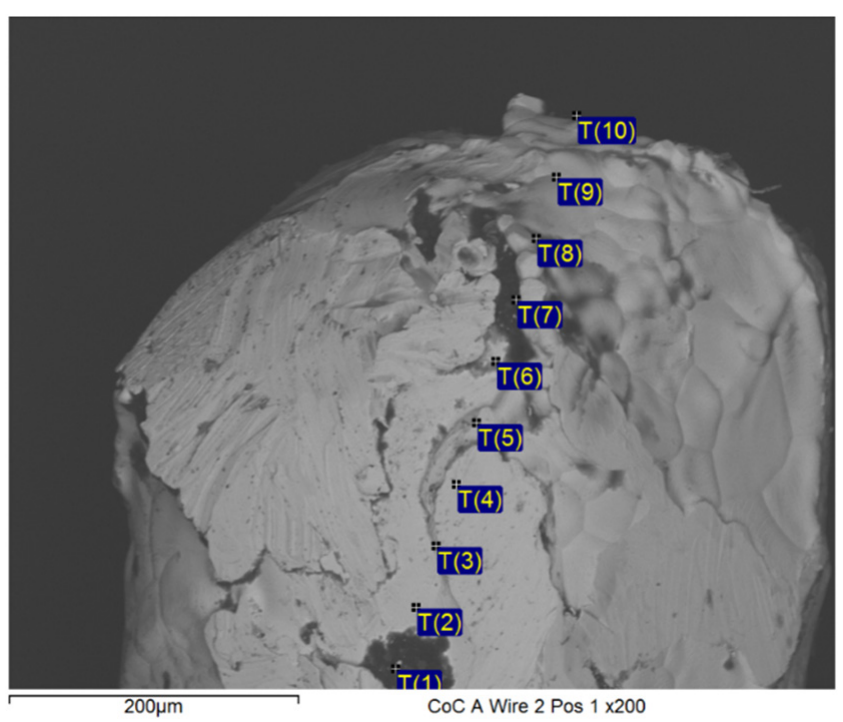

Figure 4. A example of an SEM (scanning electron microscope) image of a cross section of a broken platinum thermoelement. This example is from $\mathrm{Co}-\mathrm{C} \boldsymbol{A}$. The light grey areas are platinum, and the black areas on the wire are graphite that has migrated into the wire from the cell. This ultimately weakens the structure of the wire, causes it to become brittle, and leads to breakage.

Table 1. Shows the amount of carbon and platinum (mass fraction) at each position as indicated in the image.

\begin{tabular}{lccc}
\hline Position & Carbon $\%$ & Platinum $\%$ & Other $\%$ \\
\hline$T(1)$ & 70.31 & 13.00 & 16.69 \\
$T(2)$ & 9.74 & 86.39 & 3.87 \\
$T(3)$ & 9.71 & 81.22 & 9.07 \\
$T(4)$ & 26.77 & 70.21 & 3.02 \\
$T(5)$ & 12.74 & 85.45 & 1.81 \\
$T(6)$ & 75.49 & 9.63 & 14.88 \\
$T(7)$ & 89.28 & 0.95 & 9.77 \\
$T(8)$ & 71.53 & 12.92 & 15.55 \\
$T(9)$ & 18.28 & 71.36 & 10.36 \\
$T(10)$ & 88.50 & 0.00 & 11.50 \\
\hline
\end{tabular}

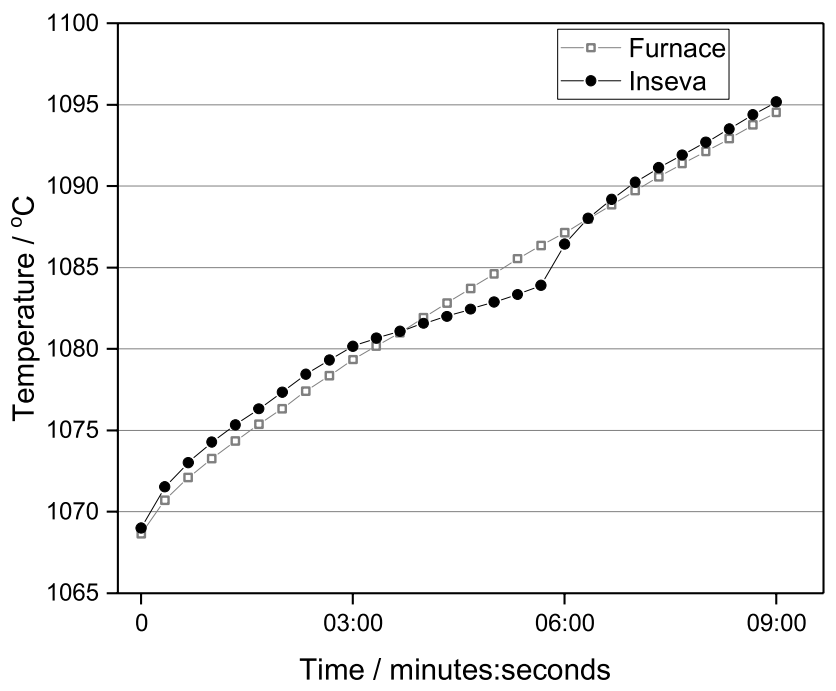

Figure 5. Temperature recorded by the ICPE-CA furnace control sensor and the inseva thermocouple. As the temperature is increased through $1084{ }^{\circ} \mathrm{C}$, the melting inflection point of the inseva fixedpoint cell can be detected clearly.

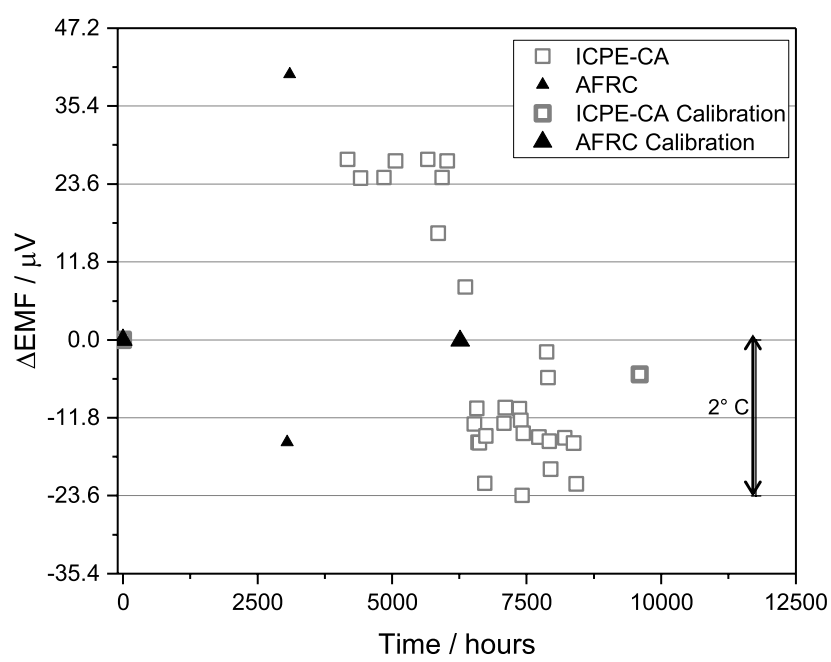

Figure 6. Melting inflection points of the two $\mathrm{Cu}$ inseva thermocouples trialled in industrial conditions. The first $(0 \mathrm{~h})$ and last points of both the ICPE-CA and AFRC data are calibrations performed in a full-size $\mathrm{Cu}$ fixed-point cell at NPL.

Table 2. The time spent by the thermocouple at different temperature ranges during the trial period. Note that the furnace temperature was not recorded for significant parts of the trial.

\begin{tabular}{lcr}
\hline & \multicolumn{2}{c}{$\begin{array}{c}\text { Recorded time spent in } \\
\text { range/h }\end{array}$} \\
\cline { 2 - 3 } Temperature range & ICPE-CA & AFRC \\
\hline$T<500{ }^{\circ} \mathrm{C}$ & 132 & 2520 \\
$500{ }^{\circ} \mathrm{C} \leqslant T<1000{ }^{\circ} \mathrm{C}$ & 116 & 1687 \\
$1000{ }^{\circ} \mathrm{C} \leqslant T<1084{ }^{\circ} \mathrm{C}$ & 29 & 1156 \\
$T \geqslant 1084{ }^{\circ} \mathrm{C}$ & 100 & 23 \\
Not recorded & 9223 & 878 \\
Total & 9600 & 6264 \\
\hline
\end{tabular}

\subsection{Industrial trials at $\mathrm{AFRC}(\mathrm{Cu})$}

After calibration at NPL, a newly manufactured $\mathrm{Cu}$ inseva thermocouple was sent to AFRC. This was then installed in the gas-fired furnace at the facility in March 2017 and removed in October 2017: experiencing a variety of industrial thermal processes - with a maximum temperature of $1150{ }^{\circ} \mathrm{C}$. During this time, two melting inflection points were reliably recorded. These are shown in figure 6 . The significant difference between the two (up to $40 \mu \mathrm{V}$, or $3.4{ }^{\circ} \mathrm{C}$ ) is likely to be due, in part, to different thermal conditions. In addition to the $\mathrm{Cu}$ melting points measured in situ, the calibration EMFs (performed in a full-sized $\mathrm{Cu}$ fixed-point cell at NPL and the start and end of trialling) are also shown in figure 6.

Several in situ melting points could not be detected due to issues with the gas burners that controlled the heating of the furnace switching on and off. Furthermore, open circuit faults also appeared on several occasions during the measurements (figure 7), which may have been caused by poor electrical contact between the thermoelements and the cell. Even so, when the thermocouple was recalibrated at NPL, a difference between the EMF at the start and end of trialling of only $0.12 \mu \mathrm{V}$ was found, demonstrating insignificant calibration drift of the thermocouple. 


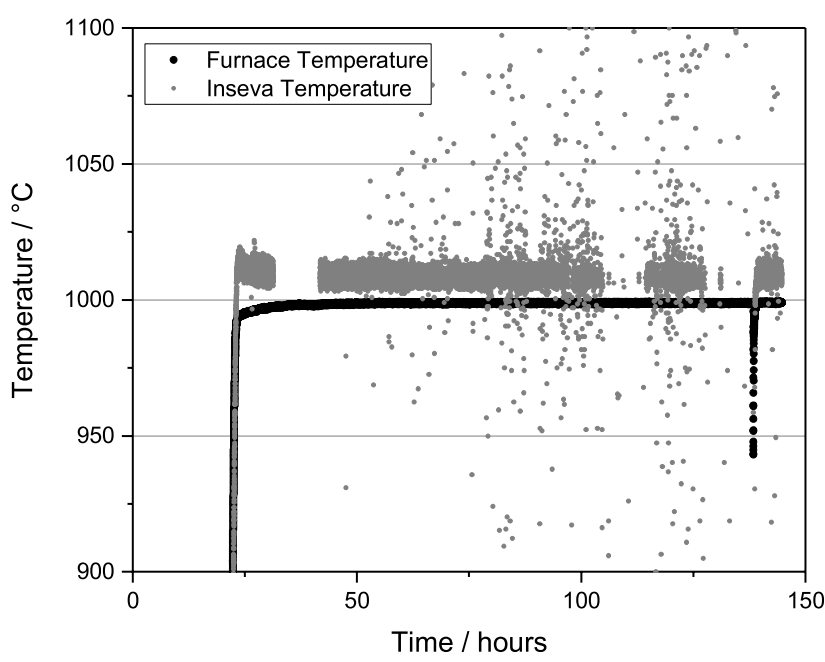

Figure 7. An example of the measurement scatter recorded while using the $\mathrm{Cu}$ inseva at AFRC.

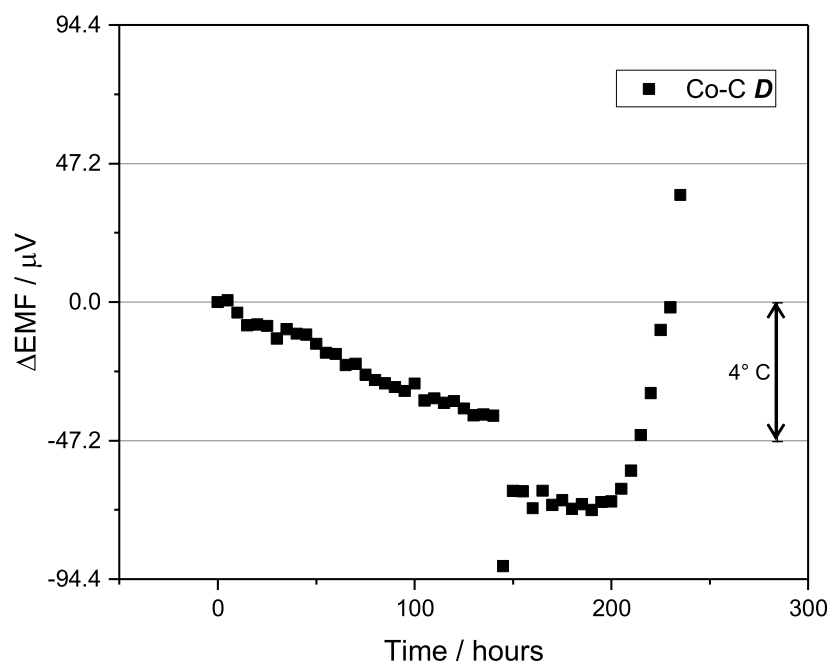

Figure 8. EMF drift measured with $\mathrm{Co}-\mathrm{C} \boldsymbol{D}$ as a function of time at high temperature, where $0 \mu \mathrm{V}$ represents the EMF of the initial melting point $(13363 \mu \mathrm{V})$. The drift over time can be seen clearly here.

The recorded scatter, which was also seen during previous work on the $\mathrm{Cu}$ inseva thermocouples was reduced when the inert barrier material was used, indicating that it improved the connection between the thermoelements and cell.

\subsection{Co-C tests at NPL}

Three Co-C inseva thermocouples were tested from their new condition, after being manufactured at NPL using the original design (without the barrier material). Co-C $\boldsymbol{A}, \boldsymbol{B}$ and $\boldsymbol{C}$ all failed during the initial testing at NPL. This was usually due to the cell cracking and breaking and the ingot leaking, which was probably caused by a combination of mechanical damage and oxidation.

Co- $C D$ contained a Co-C inseva cell coated in the inert barrier material. This thermocouple lasted $235 \mathrm{~h}$ before failing, and during this time exhibited significant calibration drift, namely a difference of $126 \mu \mathrm{V}$ between the highest and

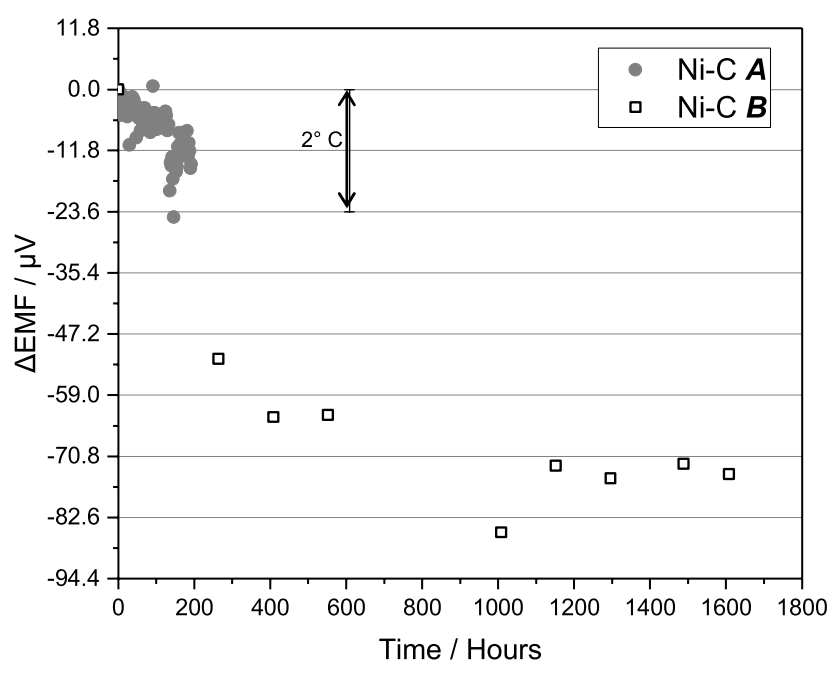

Figure 9. EMF of the melting point as a function of time during the testing of two Ni-C inseva thermocouples at NPL, both using a protective barrier around the inseva cells.

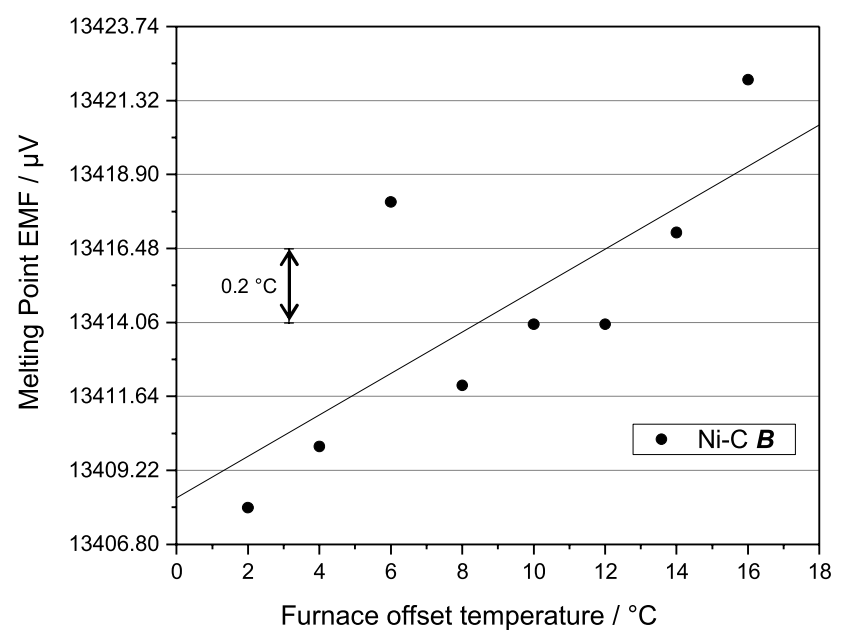

Figure 10. The relationship between the furnace offset temperature and the inflection point EMF during melting for $\mathrm{Ni}-\mathrm{C} \boldsymbol{B}$. The solid line is best fit to data, and the slope of the line is $0.73 \mu \mathrm{V}^{\circ} \mathrm{C}^{-1}$ $\left(0.061 \mu \mathrm{V} \mu \mathrm{V}^{-1}\right)$.

lowest EMF measured (figure 8). This corresponds to a stability of $\pm 5.5^{\circ} \mathrm{C}$. The linear drift seen in figure 8 up to about $150 \mathrm{~h}$ is very likely to be inherent drift of the thermocouple, while the sudden drop and subsequent rise is thought to be due to cell breakage and resulting contamination of the thermocouple wires. When the thermocouple was opened and inspected, it became clear that the cell had cracked despite the presence of the barrier material, and a small amount of the ingot had leaked out of the cell into the outer sheath, as seen in $\mathrm{Co}-\mathrm{C} \boldsymbol{A}, \boldsymbol{B}$ and $\boldsymbol{C}$.

The poor performance of the $\mathrm{Co}-\mathrm{C}$ inseva thermocouples may be attributed to the nature of the $\mathrm{Co}-\mathrm{C}$ eutectic alloy when held in a graphite crucible. The failures during this investigation were often caused by the base of the cell breaking and ingot leaking, which agrees with some previous observations of metal eutectic cells where a leakage causes a rapid change in the melting behaviour [17]. It has also been suggested that the dissolved graphite, being less dense, rises through the liquid 
Table 3. Uncertainty budget for an inseva thermocouple with a $\mathrm{Ni}-\mathrm{C}$ inseva cell.

\begin{tabular}{lllll}
\hline Uncertainty type & Uncertainty component & Standard uncertainty & Distribution & Uncertainty contribution/ $\mu \mathrm{V}$ \\
\hline Type A & $\begin{array}{l}\text { Reproducibility (of repeated meas- } \\
\text { urements) }\end{array}$ & $7.71 \mu \mathrm{V}$ & Normal & 7.71 \\
Type B & $\begin{array}{l}\text { Calibration point temperature de- } \\
\text { termination }\end{array}$ & $0.22{ }^{\circ} \mathrm{C}$ & Normal & 2.73 \\
& & & \\
& Plateau determination & $1 \mu \mathrm{V}$ & Rectangular & 0.58 \\
& Thermal environment & $1.22{ }^{\circ} \mathrm{C}$ & Rectangular & 8.74 \\
& Voltmeter calibration & $0.1 \mu \mathrm{V}$ & Normal & 0.10 \\
& Voltmeter resolution & $0.01 \mu \mathrm{V}$ & Rectangular & 0.01 \\
& Voltmeter drift & $0.1 \mu \mathrm{V}$ & rectangular & 0.06 \\
& Thermocouple inhomogeneity & $2.99 \mu \mathrm{V}$ & rectangular & 1.73 \\
& Reference junction & $0.01{ }^{\circ} \mathrm{C}$ & Rectangular & 0.01 \\
\hline & Combined standard uncertainty $/ \mu \mathrm{V}$ & & 12.11 \\
& Expanded standard uncertainty $/ \mu \mathrm{V}$ & & & 24.22 \\
& Expanded standard uncertainty, & & & $\mathbf{1 . 9 5}$ \\
& in ${ }^{\circ} \mathrm{C}$ & & \\
\hline
\end{tabular}

metal causing a lower graphite concentration at the base of the cell. This results in excessive erosion of graphite from the base of the cell which weakens and thins the cell walls [18].

Another potential issue with the $\mathrm{Co}-\mathrm{C}$ inseva cells is the trapping of gas within the ingot inside the cell, which can cause the pressure at the $\mathrm{Co}-\mathrm{C}$ melting temperature to be 5.5 times the pressure at room temperature. This can be a serious issue in the small inseva cells as the walls are much thinner than in a conventional full-size high temperature fixed point, and therefore weaker. It is particularly problematic for the Co-C cells as a smaller size of ingot was used, which leaves more space for the gas. The problem has been addressed previously by the presence of a vent in the lid of the cell [10], but it is not clear how this scheme could be arranged on the scale of the inseva cells.

\subsection{Ni-C tests at NPL}

Both Ni-C inseva thermocouples constructed at NPL made use of an inert barrier material around the cell. The results are shown in figure 9. Ni-C $\boldsymbol{A}$ was exposed continuously to temperatures above $1300{ }^{\circ} \mathrm{C}$ for around $200 \mathrm{~h}$ and a melt/freeze cycle was performed approximately every $2.2 \mathrm{~h}$. Ni-C $\boldsymbol{B}$ was tested under similar circumstances, but with the thermocouple left at 1305 ${ }^{\circ} \mathrm{C}$ for a week between melt cycles. It was tested for around $1600 \mathrm{~h}$ and the measured EMF for the melting point drifted by over $60 \mu \mathrm{V}$ in the first three cycles, but after this initial rapid apparent drift it stabilised. At the end of these tests, both of these thermocouples were still functioning.

The Ni-C $\boldsymbol{A}$ thermocouple showed very promising results, as its maximum deviation from the initial EMF reading corresponds to a change of around $2{ }^{\circ} \mathrm{C}(25 \mu \mathrm{V})$. The initial measurements for $\mathrm{Ni}-\mathrm{C} \boldsymbol{B}$ were relatively unstable: the second melting point measurement made was over $50 \mu \mathrm{V}$ lower than the initial measurement. However after this point, the EMF changed by a progressively smaller amount between each subsequent measurement, and the thermocouple appeared to stabilise to within $\pm 1{ }^{\circ} \mathrm{C}$. This could be caused by issues with the thermoelements, such as insufficient annealing [19]. Nevertheless, Ni-C inseva thermocouples appear to be much more stable and more robust than their $\mathrm{Co}-\mathrm{C}$ counterparts when used in the inseva graphite cell, and can provide an alternative at high temperatures as the $\mathrm{Co}-\mathrm{C}$ and $\mathrm{Ni}-\mathrm{C}$ melting points are only separated by $5{ }^{\circ} \mathrm{C}$.

\section{Measurement uncertainty}

Because of the poor immersion of the measurement junction in the inseva fixed-point cell (in fact it is only connected to the outside of the cell, not immersed in the ingot at all), it is essential to characterise the influence of the offset between the furnace temperature and the melting temperature on the EMF at the melting point.

As the Ni-C inseva thermocouples performed best at NPL, they were selected for a study of the sensitivity of the EMF of the inflection point to the furnace offset temperature, which is essential since the measurement junction is not immersed in the ingot. The results are presented in figure 10 for $\mathrm{Ni}-\mathrm{C} \mathbf{B}$. The inseva thermocouple was inserted into the vertical furnace described in section 3.1. The thermocouple was cycled at a ramp rate of $2{ }^{\circ} \mathrm{C} \mathrm{min}^{-1}$ to increasing offsets above and below the melting point temperature, with melting plateaux lasting between four and $10 \mathrm{~min}$. Figure 10 shows that for every increase in the furnace offset temperature corresponding to an EMF of $1 \mu \mathrm{V}$, the EMF of the melting point of the cell increases by $0.061 \mu \mathrm{V}$, which can be considered very good performance for such a small fixed-point cell. For comparison, the slope of the line for a $\mathrm{Cu}$ inseva thermocouple is $2.70 \mu \mathrm{V}^{\circ} \mathrm{C}^{-1}\left(0.229 \mu \mathrm{V} \mu \mathrm{V}^{-1}\right)$.

A representative uncertainty budget for self-calibration with the Ni-C inseva is shown in table 3, where the largest contribution to the uncertainty is found to arise from the thermal environment (specifically the offset between the furnace temperature and the fixed-point ingot melting temperature). 
The value for the thermal environment uncertainty component was taken as the maximum offset at which a plateau could still be detected. The value for the reproducibility of repeated measurements comes from the standard deviation of repeated measurements taken by $\mathrm{Ni}-\mathrm{C} \boldsymbol{B}$.

\section{Conclusions}

A study of the robustness and in-process performance of selfvalidating thermocouples with integrated miniature fixedpoint cells ('inseva' thermocouples) has been performed-and demonstrates robustness and stability which is fit for purpose in real-world applications. The inseva thermocouple has the same outward form factor as a conventional $7 \mathrm{~mm}$ outer diameter alumina sheathed thermocouple - enabling direct one-for-one replacement in industry.

The design, even without the improved barrier coating, has been shown to be robust enough to operate successfully for extended periods of time in industrial environments: melting inflection points were clearly observable when the inseva thermocouples are being heated and cooled in an industrial process, permitting in situ validation. When the effect of moving the thermocouple during the trial is disregarded, the $\mathrm{Cu}$ inseva thermocouple trialled at ICPE-CA had a stability of $\pm 1^{\circ} \mathrm{C}$ over $9600 \mathrm{~h}$.

Although the $\mathrm{Cu}$ inseva thermocouple trialled at AFRC lasted over $6000 \mathrm{~h}$, it exhibited the main problem with the design which was also found in the NPL tests: the inseva cells experience oxidation, erosion and mechanical damage over time. A total of four $\mathrm{Co}-\mathrm{C}$ inseva thermocouples were tested, but erosion and mechanical damage was found to severely limit their robustness. To address the oxidation issue, a new technique was employed to surround the fixed-point cell with an inert barrier material. Results of this improved design using $\mathrm{Cu}$ and $\mathrm{Ni}-\mathrm{C}$ ingots were presented.

The barrier coating was applied to a $\mathrm{Cu}$ inseva thermocouple which had previously been measured, which then operated again. The melting plateau stability improved to within $\pm 2.4{ }^{\circ} \mathrm{C}$ (over $1600 \mathrm{~h}$ ), compared to the original stability of $\pm 5{ }^{\circ} \mathrm{C}$ (over $1000 \mathrm{~h}$ ).

Furthermore, the alternative eutectic ingot material, $\mathrm{Ni}-\mathrm{C}\left(1329{ }^{\circ} \mathrm{C}\right)$, which has a similar melting point to $\mathrm{Co}-\mathrm{C}$ $\left(1324{ }^{\circ} \mathrm{C}\right)$ was manufactured and tested with the inert barrier coating. This proved robust enough to continue operation for durations beyond $1600 \mathrm{~h}$ with a stability better than $\pm 1{ }^{\circ} \mathrm{C}$ after the first $400 \mathrm{~h}$.

\section{Acknowledgments}

The authors would like to thank Madeleine Peck (for carrying out the SEM analysis at NPL), Mark Stewart (for assistance with the application of the inert barrier material at NPL) and CCPI Europe Ltd (for supplying the thermoelements and assisting with various aspects of the alumina shaping).

This project (14IND04 'EMPRESS'), has received funding from the EMPIR programme co-financed by the Participating
States and from the European Union's Horizon 2020 research and innovation programme. Reproduced with the permission of the Controller of Her Majesty's Stationery Office.

\section{ORCID iDs}

Declan Tucker (1) https://orcid.org/0000-0002-4173-3433

Graham Machin (1) https://orcid.org/0000-0002-8864-6951

Jonathan Pearce (D) https://orcid.org/0000-0003-1515-8815

\section{References}

[1] Elliott C J, Greenen A D, Tucker D J L and Pearce J V 2017 A slimline integrated self-validating thermocouple: initial results Int. J. Thermophys. 38141

[2] Greenen A G, Elliott C J, Lowe D, Pearce J V and Machin G 2015 Self-validation to combat thermocouple drift during high-temperature $\left(>1000{ }^{\circ} \mathrm{C}\right)$ measurement in industry MSA Conf. 2015 (Queenstown)

[3] Yamada Y, Sakate H, Sakuma F and Ono A 1999 A possibility of practical high temperature fixed points above the copper point 7th Int. Symp. on Temperature and Thermal Measurements in Industry and Science (Delft) 2535

[4] Pearce J V, Elliott C J, Machin G and Ongrai O 2013 Selfvalidating type $\mathrm{C}$ thermocouples to $2300{ }^{\circ} \mathrm{C}$ using high temperature fixed points AIP Conf. Proc. 1552595

[5] Ongrai O, Pearce J V, Machin G and Sweeney S J 2011 A miniature high-temperature fixed point for self-validation of type C thermocouples Meas. Sci. Technol. 22105103

[6] Failleau G, Elliott C J, Deuzé T, Pearce J V, Machin G and Sadli M 2014 Miniature fixed-point cell approaches for in situ monitoring of thermocouple stability Int. J. Thermophys. 35 1223-38

[7] Edler F, Haput S, Mokdad S-A, Failleau G and Sadli M 2015 Investigation of self-validating thermocouples with integrated fixed-point units Int. J. Metrol. Qual. Eng. 6103

[8] Krapf G, Froehlich T, Augustin S, Mannen H, Blumroeder G, Schalles M and Hilbrunner F 2011 Long term stability of miniature fixed-point cells used in self-calibrating thermometers Proc. SENSOR 2011 (Nürnberg) (https://doi. org/10.5162/sensor11/sp3.4)

[9] Woolliams E R, Machin G, Lowe D H and Winkler R 2006 Metal (carbide)-carbon eutectics for thermometry and radiometry: a review of the first seven years Metrologia 43 R11

[10] Tischler M and Koremblit M J 1982 Miniature thermometric fixed points for thermocouple calibrations Temperature: Its Measurement and Control in Science and Industry American Institute of Physics, New York 1982 vol 5 pp 383-90

[11] Elliott C J, Pearce J, Machin G, Schwarz C and Lindner R 2012 Self-validating thermocouples for assured temperature measurement confidence and extended useful life 12th European Conf. on Spacecraft Structures, Materials and Environmental Testing 2012 (Ouwehand)

[12] Elliott C J, Large M J, Pearce J V and Machin G 2014 Compatibility of materials for use at high temperatures with W-Re thermocouples Int. J. Thermophys. 35 1202-14

[13] Lowe D and Yamada Y 2006 Reproducible metal-carbon eutectic fixed-points Metrologia $\mathbf{4 3} 135$ 
[14] Ongrai O, Pearce J V, Machin G and Sweeney S J 2011 Miniature $\mathrm{Co}-\mathrm{C}$ eutectic fixed-point cells for self-validating thermocouples Meas. Sci. Technol. 22015104

[15] Lowe D and Machin G 2012 Evaluation of methods for characterizing the melting curves of a high temperature cobalt-carbon fixed point to define and determine its melting temperature Metrologia 49 189-99

[16] Edler F, Ederer P, Baratto A C and Vieira H D 2007 Melting temperatures of eutectic fixed-point cells usable for the calibration of contact thermometers Int. J. Thermophys. 28 1983-92
[17] Lehmann H 2010 Fixed-point thermocouple in power plants: long-term operational experiences Int. J. Thermophys. 31 1599-607

[18] Sadil M, Bourson F, Fanjeaux M, Briaudeau S, Rougié B and Bonnier G 2004 Study of metal-carbon eutectic points: from construction to temperature determination 9th Int Symp. on Temperature and Thermal Measurements in Industry and Science (Dubrovnik) p 611

[19] Pearce J V, Greenen A G, Smith A and Elliott C J 2017 Relating composition and thermoelectric stability of Pt-Rh alloy thermocouples Int. J. Thermophys. 3826 